\title{
ШЛЯХИ ОПТИМІЗАЦІЇ ДІАГНОСТИЧНОГО ПРОЦЕСУ ТА ПРОГНОСТИЧНИХ КРИТЕРІЇВ КЛІНІЧНОГО ПЕРЕБІГУ ГЕНЕРАЛІЗОВАНОГО ПАРОДОНТИТУ
}

\author{
ДВНЗ «Тернопільський державний медичний університет імені І.Я. Горбачевського \\ МОЗ України»
}

\begin{abstract}
Мета: оптимізувати діагностичний процес пародонтологічних пацієнтів і запропонувати шляхи прогнозування клінічного перебігу генералізованого пародонтиту та визначення адекватного комплексу місцевих втручань.

Матеріали і методи. Матеріалом для дослідження слугував вміст пародонтальних кишень, забраний у 55 осіб чоловічої статі молодого віку. Основним критерієм відбору серед даного контингенту була відсутність шкідливих звичок та супутньої соматичної патології.

Результати. Застосування запропонованого алгоритму обстеження, який включає дослідження клітинного складу пародонтальних кишень та імуногістохімічного профілю клітинних інфільтратів власної пластинки ясен, морфологічних та цитоспецифічних змін епітелію при пародонтиті, дає можливість доповнити арсенал існуючих традиційних методів діагностики в пародонтології більш точними і високоспецифічними та запропонувати ряд морфологічних прогностичних критеріїв клінічного перебігу даної нозологічної одиниці.

Висновки. Проведений статистичний аналіз дає можливість виділити «нейтрофільний», «макрофагальний» та «моноцитарний» типи мазків-зскрібків за умов хронічного перебігу генералізованого пародонтиту.
\end{abstract}

КЛЮЧОВІ СЛОВА: оптимізація, алгоритм, пародонтальна кишеня, клітини, ядро, цитоплазма.

У теперішній час запальні та запально-дистрофічні захворювання тканин пародонта є домінуючими в загальній структурі патологічних процесів порожнини рота [4].

Вогнище хроніоінфекції у пародонті спроможне не лише інфікувати тканини щелепно-лицевої ділянки, але й ініціювати виникнення захворювань, пов'язаних із системним запаленням, таких як ревматизм та колагенози. Наявність великої кількості епідеміологічних та клінічних досліджень вказує на зв'язок між серцево-судинною патологією та персистуючими бактеріальними інфекціями або клінічними станами із пародонтитом [2].

Хронічне запалення тканин пародонта супроводжується різким підвищенням рівня прозапальних цитокінів ІЛ-1в, TNF-б, активності лактатдегідрогенази, аспартатамінотрансферази, супероксиддисмутази [1].

C-реактивний протеїн, TNF-б, підвищений рівень лейкоцитів крові можуть слугувати незалежними факторами ризику виникнення атеросклерозу, стенокардії. Їх вивільнення при загостренні інфекційного процесу ініціює каскад біохімічних реакцій, що є безпосередньою причиною пошкодження ендотелію ендокарда і судин [3;5].

Доведено, що такі захисні реакції організму, як фагоцитоз та імуногенез, спрямовані на ней-

(C) Н.В. Гасюк, 2015 тралізацію мікробного фактора, ініціюють патологічні механізми деструкції тканин пародонта [6;7]. При цьому відбуваються імунологічні реакції, що забезпечують взаємозв'язок хронічної персистуючої інфекції у пародонті із кардіоваскулярними та нейроваскулярними захворюваннями - перехресні імунні реакції, автоімунні пошкодження, стан імунодефіциту [10].

Наявність двоспрямованого зв'язку між особливостями клінічного перебігу генералізованого пародонтиту та станом макроорганізму, дає можливість визначення патогенетичних ланцюгів розвитку даної нозологічної одиниці. Оскільки в організмі хворих утворюються антитіла не лише до мікроорганізмів та лізованих клітинних структур пародонтальних кишень, а й власне проти патологічно змінених тканин пародонта. Наростання цих імунологічних змін та зрушення в імунологічних реакціях клітинного та гуморального типу призводить у подальшому до руйнації клінічно не змінених тканин пародонта [11].

Потребує новітніх підходів до профілактики та лікування даного захворювання гіпотеза стосовно єдності генетичної детермінованості та схильності до запальних захворювань, що розвиваються в тканинах пародонта.

Метою дослідження стала оптимізація діагностичного процесу пародонтологічних пацієнтів шляхом вивчення клітинного складу, морфологічних та цитоспецифічних змін епітелію і власної пластинки ясен, що дає можливість прогно- 
зування клінічного перебігу генералізованого пародонтиту та визначення адекватного комплексу місцевих втручань.

Робота є фрагментом проекту Науково-дослідного інституту генетичних та імунологічних основ розвитку патології та фармакогенетики (м. Полтава) «Роль запальних захворювань зубо-щелепного апарату в розвитку хвороб, пов'язаних із системним запаленням», номер державної реєстрації №0112U0011538. Автор є співвиконавцем даного проекту.

Матеріали і методи. Матеріалом для дослідження слугував вміст пародонтальних кишень, забраний у 55 осіб чоловічої статі молодого віку. Основними критеріями відбору серед даного контингенту були відсутність шкідливих звичок та супутньої соматичної патології. Епітелій забирали шпателем з подальшим перенесенням на предметне скло і висушуванням при відкритому доступі повітря протягом 3-5 хвилин. Забарвлення матеріалу проводили за Гімзою-Романовським, з подальшим мікроскопічним і морфологічним аналізом, з урахуванням процентного співвідношення різних форм епітеліоцитів у нормі.

Діагностичне обстеження проводили згідно із стандартами діагностики і лікування стоматологічних хворих (наказ МОЗ України «Про затвердження протоколів надання медичної допомоги за спеціальностями «ортопедична стоматологія», «терапевтична стоматологія», «хірургічна стоматологія», «ортодонтія», «дитяча терапевтична стоматологія», «дитяча хірургічна стоматологія» від 28.12.2002 №507 та наказ МОЗ України «Про затвердження нормативів надання медичної допомоги та показників якості медичної допомоги» від 28.12.2002 № 507) [8].

Критеріями постановки діагнозу в осіб обстеженого контингенту слугували:

1) молодий вік пацієнтів (від 21 до 35 років, згідно з віковим розподілом ВООЗ);

2) анамнестичні дані пацієнтів (тривалість захворювання від 1 до 3 років та частота загострень на рік);

3) дані об'єктивного обстеження (генералізований і прогресуючий характер деструкції кісткової тканини).

Постановку діагнозу проводили згідно з класифікацією захворювань пародонта М.Ф. Данилевського (1994) [9].

Статистичну обробку результатів дослідження виконано у відділі статистичних досліджень ДВНЗ «Тернопільський державний медичний університет імені І.Я. Горбачевського МОЗ України». Параметричні методи застосовували для показників, розподіл яких відповідав вимогам нормальності. Для оцінки характеру розподілу визначалися коефіцієнт асиметрії та ексцес.
Перевірку нормальності проводили за тестом асиметрії Шапіро-Вілка. Достовірність відмінностей отриманих результатів для різних груп визначалася за допомогою t-критерію Стьюдента. Відмінності вважали достовірними за загальноприйнятої у медико-біологічних дослідженнях ймовірності помилки р<0,05. Імовірність помилки оцінювали за таблицями Стьюдента з урахуванням розміру експериментальних груп. У випадках, коли закон розподілу статистично достовірно відрізнявся від нормального, розраховували непараметричний критерій (U) МаннаВітні як непараметричний аналог t-критерію Стьюдента.

Результати дослідження та їх обговорення. Клітинний склад пародонтальних кишень, за умов хронічного перебігу генералізованого пародонтиту, представлений епітеліальними та гематогенними клітинами. Серед епітеліоцитів привертає увагу поява в цитограмах базальних клітин, які в нормі відсутні, кількість їх складає $(14,2 \pm 0,23)$. Вони мають призматичну форму, овальне ядро, ядерце зміщене на периферію та характеризуються різкою базофілією цитоплазми. Ядерно-цитоплазматичне співвідношення (ЯЦС) високе - $(0,49 \pm 0,002)$, зміщене у бік ядра, що дає можливість ідентифікувати дану клітину як базальну - першого ступеня диференціації.

Поява базальних клітин дає можливість стверджувати про глибоке ураження епітелію запальним процесом і характеризує ступінь тяжкості пародонтиту в осіб обстеженого контингенту. У клітинах наявні ознаки цитопатології. Характерною особливістю цитограм осіб обстеженого контингенту є відсутність парабазальних клітин, як наслідок клітин другого ступеня диференціації.

Характерним для даних цитограм є наявність проміжних клітин у кількості $(34,9 \pm 0,28)$. Вони мають полігональну форму, оптично світлу цитоплазму, ексцентрично зміщене овальне везикулярне ядро. Ядерно-цитоплазматичне співвідношення зменшується у бік ядра, що дає можливість віднести дані клітини до третього рівня диференціації.

Поверхневі епітеліоцити в цитограмах пародонтальних кишень візуалізуються в двох типах, належність до яких визначаємо за станом ядра.

Перший тип поверхневих клітин, у кількості $(20,1 \pm 0,26)$, представлений епітеліоцитами, розміри яких більші за проміжні, чітко оконтуроване ядро звичайних розмірів, розміщене по центру клітини. Ядерно-цитоплазматичне співвідношення зміщується у бік цитоплазми і складає

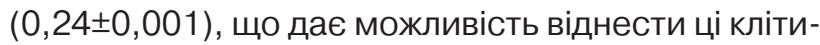
ни до четвертого рівня диференціації.

Другий тип поверхневих клітин представлений поверхневими епітеліоцитами у кількості

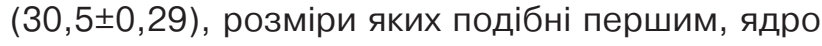


пікнотичне, характеризується чіткими контурами, нерідко в ньому зустрічаються незабарвлені вакуолі, каріолізис та фрагментація з подальшою еліменацією із цитоплазми. Ядерно-цитоплазматичне співвідношення зміщується у бік цитоплазми і становить $(0,10 \pm 0,001)$, що дає можливість віднести ці клітини до четвертого рівня диференціації.

Дослідження мазків-зскрібків пародонтальних кишень, за умов загострення генералізованого пародонту, показують, що епітеліальний клітинний склад залишається сталим, але звертає особливу увагу зміна кількісного співвідношення епітеліальних клітин.

Кількість клітин із ЯЦС $(0,49 \pm 0,002)$, що відповідає базальним епітеліоцитам, вірогідно збільшилась і становить $(23,8 \pm 0,31)$. Парабазальні епітеліоцити за аналогією мазків-зскрібків ГП хронічного перебігу відсутні. Кількість проміжних клітин, ЯЦС яких становить 0,35 $\pm 0,001$, вірогідно зменшилась і становить $(32,8 \pm 0,21)$. В той час як кількісний склад клітинних фракцій поверхневого шару із центрично розташованим ядром із ЯЦС $(0,24 \pm 0,001)$ вірогідно збільшується і становить $(37,7 \pm 0,23)$, в той час як кількість поверхневих епітеліоцитів із пікнотичними ядром та ЯЦС $(0,10 \pm 0,001)$ вірогідно зменшилась і становить $(6,7 \pm 0,16)$.

Вищенаведена динаміка змін клітинного складу епітеліоцитів дає можливість стверджувати, що за умов тривалого запального процесу в пародонті спостерігається відсутність усіх клітин диферону епітеліальної клітини та зміна відсоткового співвідношення клітинних авангардів.

Серед клітин гематогенного ряду в цитограмах вмісту пародонтальних кишень визначається велика кількість нейтрофільних гранулоцитів, на різних стадіях фагоцитозу, що мають гіперсегментовані ядра, без перемичок між сегментами. Їх кількість становить $(65,6 \pm 0,18)$. Слід зазначити, що даний вид клітин перебував у цитограмах незалежно від перебігу генералізованого пародонтиту, проте їх функціональний стан змінювався.

За умов хронічного перебігу нейтрофільні гранулоцити утворюють клітинні скупчення. При цьому чітко візуалізуються контури плазмолеми, форма клітин здебільшого округла, зберігається сегментація ядер. Кількість макрофагів при цьому становить $(8,6 \pm 0,14)$, моноцитів $(5,7 \pm 0,17)$, лімфоцитів $(20,1 \pm 0,18)$.

Даний тип мазка за умов хронічного клінічного перебігу корелює з анамнестичними даними пацієнтів стосовно частоти загострень 3-4 рази на рік та є прогностичним критерієм високої вірогідності загострень.

У ряді цитограм у досить великій кількості $(36,9 \pm 0,38)$ визначалися макрофаги, які мають видовжену форму, оптично щільне ядро, при цьому кількість лейкоцитів вірогідно зменшується і становить $(29,6 \pm 0,21)$ за умови зростання кількості моноцитів $(12,6 \pm 0,21)$ та незначного зростання лімфоцитів $(20,9 \pm 0,16)$. У цитоплазмі макрофагів міститься добре розвинений лізосомальний апарат, в той час як інші органели розвинені помірно. Їх кількісний склад пояснюється постійною необхідністю фагоцитозу некротизованих тканин та компонентів міжклітинної речовини та мікроорганізмів у пародонтологічному вогнищі запалення. Окрім того даний вид клітин бере участь в індукції імунних реакцій шляхом процесингу антигенів та презентації їх лімфоцитам, регулюють діяльність інших типів клітин, у тому числі і фібробластів. Поряд із функціонально активними макрофагами в цитограмах зустрічаються і лізовані клітини, контури плазмолеми яких порушені, ядро знаходиться на стадії. Окрім клітин макрофагальної системи візуалізуються еритроцити, які при забарвленні за Грамом мають вигляд двояко ввігнутих дисків, що в процесі філогенезу втратили ядро. Цитоплазма їх слабо забарвлюється і характеризується оксифілією.

Даний тип мазка за умов хронічного клінічного перебігу корелює із анамнестичними даними пацієнтів стосовно частоти загострень генералізованого пародонтиту 2-3 рази на рік, що дає можливість характеризувати його як прогностичний критерій «відносно низької вірогідності загострень».

Привертає увагу перевага в ряді цитограм моноцитів у кількості $(35,4 \pm 0,28)$, які мають овальну форму з бобоподібним несегментованим ядром великих розмірів, багатим на хроматин. Цитоплазма клітин порівняно великих розмірів, містить добре розвинений лізосомальний апарат. При цьому кількість лейкоцитів та макрофагів достовірно зменшилась і складає $(23,2 \pm 0,31)$ та $(14,7 \pm 0,22)$ відповідно. Переважання даних клітин у мазках вказує на функціональну активність мезенхіми і характеризує слабку тенденцію до загострення хронічного процесу. Даний тип мазка за умов хронічного клінічного перебігу корелює із анамнестичними даними пацієнтів стосовно частоти загострень 0-1 разів на рік, є прогностичним критерієм «низької вірогідності загострень».

У всіх цитограмах за умов хронічного перебігу пародонтиту візуалізуються лімфоцити, які мають велике кулястої форми ядро, розміщене переважно по центру, що займає майже всю клітину, містить велику кількість дифузно розміщеного гетерохроматину.

3 метою цитологічної ідентифікації нами проведено дослідження цитоспецифічних властивостей лімфоцитів пародонтальних кишень. Цитоплазма лімфоцитів характеризується базофілією, забарвлюється в світло-блакитний колір і оточує 
ядро у вигляді вузької облямівки. У цитоплазмі візуалізується світла перинуклеарна зона.

Наявність у цитограмах лімфоцитів підтверджує отримані нами результати комплексних гістологічних та імуногістохімічних досліджень стосовно залучення імунної системи і хронізації процесу та наявності взаємозв'язку вогнища хронічної інфекції тканин пародонта із рядом системних запальних процесів в організмі.

За умов загостреного клінічного перебігу генералізованого пародонтиту спостерігаються зміни якісних характеристик нейтофільних гранулоцитів. При цьому кількість лізованих нейтрофільних гранулоцитів вірогідно збільшилась і становить $(12,4 \pm 0,98)$ порівняно із мазкамизскрібками при хронічному перебігу $(1,6 \pm 0,22)$. Більшість із них $є$ дегенеративно зміненими, із гіперсегментованими ядрами, без з'єднань між ними, специфічна зернистість відсутня.

Отже, результати проведених нами досліджень мазків-зскрібків пародонтальних кишень дають можливість спостерігати зміни якісного та кількісного складу як епітеліальної, так і сполучнотканинної їх складової. При генералізованому пародонтиті в стадії загострення, порівняно 3

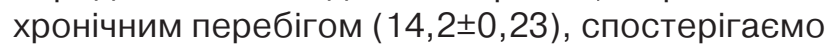
вірогідне збільшення кількості базальних епітеліоцитів $(23,8 \pm 0,30)$, що свідчить про високу інтенсивність запально-деструктивних змін у тканинах пародонта та активацію проліферативної здатності базального шару.

Кількість проміжних клітин дещо зменшилась порівняно з ідентичним класом клітин за умов хронічного перебігу $(34,9 \pm 0,28)$ і становить $(32,8 \pm 0,21)$, що свідчить про порушення перебігу процесів диференціації епітеліальних клітин. Кількість поверхневих клітин із ядром без пікнозу у мазках-зскрібках за умов хронічного перебігу становить $(20,1 \pm 0,26)$, епітеліоцитів із пікнотичним ядром - $(30,5 \pm 0,28)$, що свідчить про шляхи зроговіння епітелію кишень шляхом паракератозу. За умов загостреного клінічного перебігу відмічаємо вірогідне збільшення кількості поверхневих епітеліоцитів із ядрами без пікнотичних змін за умови вірогідного зменшення клітин із пікнотичними ядрами, що свідчить про порушення зроговіння епітелію, ініційоване запальною реакцією строми, та розвиток порушення зроговіння у вигляді дискератозу.

За умов хронічного та загостреного клінічного перебігу достовірно відрізняються кількісні показники функціонального стану нейтрофілів. Так, кількість лізованих лейкоцитів, яка при пародонтиті хронічного перебігу становить $(1,6 \pm 0,22)$, достовірно збільшується при загостренні і становить $(12,4 \pm 0,98)$, що відображає незавершеність фагоцитарної реакції та забезпечує клінічну картину даного перебігу.
Привертає увагу інтенсивна мікробна контамінація мазків-зскрібків пародонтальних кишень, серед представників якої визначаються складні комплекси, палички, коки та гриби роду Candida, спірили. За умов прогресування генералізованого пародонтиту відбувається зміна мікробного складу умовно-патогенних штамів мікроорганізмів на інші, більш патогенні та патогенні, мікроорганізми із виразною асоціацією до захворювань пародонта.

Патогенні мікроорганізми можуть бути причиною пошкодження тканин пародонта за двох причин: власне бактеріальної і токсичної дії та як відповідь тканин пародонта на вплив мікробного чинника.

При генералізованому пародонтиті ініціюється каскад клітинних реакцій поліморфноядерних лейкоцитів та макрофагів, які потрапили під деструктивний вплив мікробних агентів. Статистична обробка отриманих нами результатів стосовно змін сполучнотканинних клітинних компонентів мазків-зскрібків дає можливість прогнозування загострень пародонтиту за умов хронічного перебігу. Сегментоядерні лейкоцити є невід'ємною складовою, проте їх максимальна кількість $(65,6 \pm 0,18)$ корелює із частотою загострень 3-5 разів. Резидентність лейкоцитів та їх кількісні зміни вказують на постійну персистенцію пародонтопатогенних мікроорганізмів, що призводить до утворення в тканинах пародонта комплексу високоактивних сполук - цитокінів, які здатні модифікувати активність нейтрофільних гранулоцитів і знижувати їх специфічні бактерицидні властивості. Цитокіни не лише несприятливо впливають на тканину пародонта, але й викликають подальшу активацію клітин, що їх синтезували, пригнічують тканинну репарацію та процес ресинтезу фібробластами сполучної тканини.

Максимальна кількість у мазках-зскрібках макрофагів $(36,9 \pm 0,38)$ корелює із частотою загострень 2-3 рази на рік. Перевага моноцитів у кількості $(35,4 \pm 0,28)$ характеризується наявністю кореляційних зв'язків із частотою загострень 0-1 разів на рік, при цьому кількість сегментоядерних лейкоцитів та макрофагів достовірно зменшується і складає $(5,7 \pm 0,17)$ та $(12,6 \pm 0,21)$. Кількісні зміни лімфоцитів за умов різної частоти загострень є незначними і становлять $(20,1 \pm 0,18)$ при частоті загострень $3-5$ разів на рік, $(20,9 \pm 0,16)$ при частоті загострень 2-3 рази на рік та $(26,6 \pm 0,47)$ при частоті загострень 3-5 разів на рік. Наявність лімфоцитів відображає напруженість гуморального ланцюга імунної системи.

Виходячи із зазначеного, нами розроблено морфологічний алгоритм обстеження пацієнтів молодого віку, хворих на генералізований пародонтит різного ступеня важкості (рис.). 


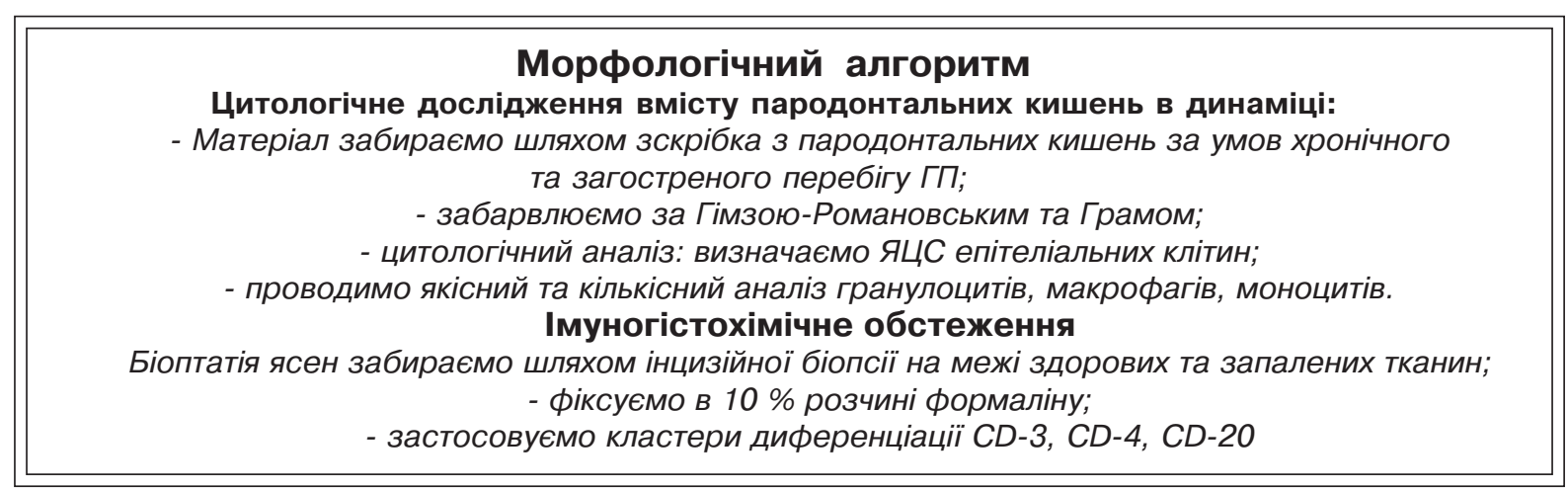

Рис. Морфологічний алгоритм обстеження хворого на генералізований пародонтит

\section{Висновки}

Проведений статистичний аналіз дає можливість виділити «нейтрофільний», «макрофагальний» та «моноцитарний» типи мазків-зскрібків за умов хронічного перебігу генералізованого пародонтиту.

Отримані результати досліджень дають можливість стверджувати про високу діагностичну інформативність цитологічного методу дослідження, зокрема у пародонтології.

Перспективи подальших досліджень. Планується розглянути патогенетичні механізми виникнення генералізованого пародонтиту через поліморфізм ядерного фактора транскрипції NFkв1, який контролює експресію генів імунної відповіді, апоптозу і клітинного циклу.

\section{Список літератури}

1. Бойченко О. М. Прооксидантно-антиоксидантний стан крові та ротової рідини у хворих на генералізований пародонтит на тлі ішемічної хвороби серця / О. М. Бойченко, О. П. Ступак, Н. В. Гасюк // Актуальні проблеми сучасної медицини : вісн. УМСА. - 2014. - № 3 (47). - С. 4-7.

2. Бойченко О. М. Структура та захворюваність хвороб пародонта у пацієнтів із ішемічною хворобою серця / О. М. Бойченко, Н. В. Гасюк, О. В. Палій // Світ медицини і біології. - 2013. - № 1 (36). - С. 21-22.

3. Гасюк Н. В. Особенности клеточного состава десен больных пародонтитом / Н. В. Гасюк, О. Н. Бойченко // Актуальные вопросы медицинской науки : материалы науч. конф. студентов-медиков и молодых ученых с междунар. уч. - Самарканд, 2014. - С. 21-22.

4. Гасюк Н. В. Структура та поширеність хвороб пародонта у осіб молодого віку / Н. В. Гасюк // Південноукр. мед. журн. - 2013. - № 3 (03). - С. 36-37.

5. Гасюк П. А. Особливості морфологічної будови ясен в нормі і при хронічних гінгівітах : навч. посібн. для студентів вищих медичних навчальних закладів III-IV рівнів акредитації / П. А. Гасюк, Н. В. Гасюк. - Тернопіль, 2014.- 92 с.

6. Грудянов А. И. Заболевания пародонта / А. И. Грудянов. - М. : Мед. информ. аг., 2009. - 336 с.

7. Мошель Т. М. Характеристика клітинного складу мазків пародонтальних кишень (матеріали конференції, присвяченої 90-річчю ВДНЗ України «УМСА», Полтава, 2011) / Т. М. Мошель, Н. В. Гасюк, Г. А. Єрошенко // Проблеми екології та медицини. - 2011. - Т.15, № 34 (дод. 1). С. 114115.

8. Про затвердження протоколів надання медичної допомоги за спеціальностями «ортопедична стоматологія», «терапевтична стоматологія», «хірургічна стоматологія», «ортодонтія», «дитяча терапевтична стоматологія», «дитяча хірургічна стоматологія» : наказ МОЗ України від 28.12.2002 № 507 [Електронний документ]. - Режим доступу : http://www.moz.gov.ua. - Назва з екрану.

9. Терапевтична стоматологія : захворювання пародонта // Данилевський М. Ф., Борисенко А. В., Політун А. М. [та ін.]. - К. : Медицина, 2008. - 610 с.

10. Kornman K. S. Mapping the pathogenesis of periodontitis: a new look / K. S. Kornman // J. Periodontol. - 2008. Vol. 79, № 8. - P. 1560568.

11. Kornman K. S. The «innovator's dilemma» for periodontists / K. S. Kornman, D. Clem // J. Periodontol. - 2010. Vol. 81, № 5. - P. 646649.

\section{ПУТИ ОПТИМИЗАЦИИ ДИАГНОСТИЧЕСКОГО ПРОЦЕССА И ПРОГНОСТИЧЕСКИХ КРИТЕРИЕВ КЛИНИЧЕСКОГО ТЕЧЕНИЯ ГЕНЕРАЛИЗОВАННОГО ПАРОДОНТИТА}

Н.В. Гасюк

ГВУЗ «Тернопольский государственный медицинский университет имени И.Я. Горбачевского МЗ Украины»

Цель: оптимизировать диагностический процесс пародонтологических пациентов и предложить пути прогнозирования клинического течения генерализованного пародонтита и определения адекватного комплекса местных вмешательств. 
Материалы и методы. Материалом для исследования служило содержимое пародонтальных карманов 55 лиц мужского пола молодого возраста. Основными критериями отбора среди данного контингента были отсутствие вредных привычек и сопутствующей соматической патологии.

Результаты. Применение предложенного алгоритма обследования, включающего исследование клеточного состава пародонтальных карманов и иммуногистохимического профиля клеточных инфильтратов собственной пластинки десны, морфологических и цитоспецифичних изменений эпителия при пародонтите, дает возможность дополнить арсенал существующих традиционных методов диагностики в пародонтологии более точными и высокоспецифическими, а также предложить ряд морфологических прогностических критериев клинического течения данной нозологической единицы.

Выводы. Проведенный статистический анализ позволяет выделить «нейтрофильный», «макрофагальный» и «моноцитарный» типы мазков-соскобов в условиях хронического течения генерализованного пародонтита.

КЛЮЧЕВЫЕ СЛОВА: оптимизация, алгоритм, пародонтальный карман, клетки, ядро, цитоплазма.

\section{WAYS OF OPTIMIZATION OF DIAGNOSTIC PROCESS AND PROGNOSTIC CRITERIA OF CLINICAL COURSE OF GENERALIZED PERIODONTITIS}

N.V. Gasiuk

SHEI "Ternopil State Medical University named after I.Ya. Gorbachevskiy Ministry of Health of Ukraine"

Objective: optimize the diagnostic process of periodontal patients and suggest ways of prediction of clinical course of generalized periodontitis and definitions of adequate complex of local interventions.

Materials and methods. Material for the study served content periodontal pockets, gathered in 55 males younger. The main criterion for selection among this contingent were: lack of bad habits and concomitant somatic pathology.

Results. Application of the proposed algorithm survey, which includes the study of cellular structure periodontal pockets and immunohistochemical profile of cell infiltration of the lamina propria of the gums, and morphological changes cytospecific epithelium in periodontitis, makes it possible to supplement the existing arsenal of conventional diagnostic methods in periodontology more accurate and highly specific, and offer a number of morphological criteria prognostic clinical course of nosological unit.

Conclusions. Statistical analysis makes it possible to distinguish "neutrophil", "macrophage" and "monocytic" types smear-scraps flow under conditions of chronic generalized periodontitis.

KEY WORDS: optimization, algorithm, periodontal pocket, cells, nucleus, cytoplasm.

Рукопис надійшов у редакцію 02.02.2015 р.

Відомості про автора:

Гасюк Наталія Володимирівна - к.мед.н., доц. кафедри терапевтичної стоматології ДВНЗ «Тернопільський державний медичний університет імені І.Я. Горбачевського МОЗ України»; тел.: + 38 (0352)-25-98-02. 